\title{
Copyright formalities: A return to registration?
}

\author{
Dev S Gangjee
}

\section{Introduction}

Among the regimes constituting the field of intellectual property (IP) law, copyright stands apart. Unlike patent, trademark or (with some qualifications) design protection, ${ }^{2}$ the recognition and enforcement of proprietary interests is automatic, arising upon creation. It is not conditioned upon the fulfilment of formalities. ${ }^{3}$ This relative informality of copyright is celebrated as a virtue, as well as a necessary by-product of underlying normative commitments. However the ease with which proprietary rights are generated, their profusion and the ensuing difficulty of keeping track of them have led to calls for the (re)introduction of formalities, to bring some much-needed clarity to copyright entitlements. ${ }^{4}$

1 Faculty of Law, University of Oxford. I am profoundly grateful to the editors and my fellow contributors for comments during the workshop in Strasbourg (2014), which initiated this project, as well as to Jane Ginsburg for insightful suggestions and gentle rebuke.

2 While designs are protected via various registration-based regimes, they are also accommodated under copyright, unfair competition and unregistered designs systems. For a comprehensive review of national laws, see WIPO Secretariat, Summary of Replies to the Questionnaires (Parts I and II) on Industrial Design Law and Practice (SCT/18/7 and SCT/18/8 Rev.), WIPO/Strad/INF/2 Rev.2 (19 June 2009).

3 S Dusollier, Scoping Study on Copyright and Related Rights and the Public Domain, WIPO Committee on Development and Intellectual Property, CDIP/7/INF/2 (4 Mar 2011), Annex 32.

4 The arguments of proponents and opponents are considered in Section 3 below. 
Most other contemporary IP regimes continue to prescribe mandatory formalities - pre-eminently, registration ${ }^{5}$ - as does real property, in the form of land registration. What's more, copyright was not always an outlier in this regard. Until the late 19th and early 20th centuries, formalities such as the registration of ownership, periodic renewal requirements, recording the transfer of ownership, signalling notice of protected status and the deposit of protected subject matter featured prominently in national copyright regimes. ${ }^{6}$ The question taken up in this chapter is whether it would be in the public interest to adopt mandatory formalities once again and, if so, which ones.

The reintroduction of formalities is particularly suited to a thought experiment. A blank canvas seems necessary because the writing is otherwise on the wall, in the form of article 5(2) of the Berne Convention: "The enjoyment and the exercise of these [Convention and national law] rights shall not be subject to any formality'. ${ }^{7}$ This prohibition was subsequently reinforced, via its incorporation into the TRIPS Agreement and the WIPO Copyright Treaty. ${ }^{8}$ While a Berne Union member remains free to impose formalities on its own nationals or works produced within that jurisdiction under article 5(3), works produced by non-domestic authors or initially published elsewhere cannot be subjected to formalities affecting the enjoyment (recognition) or exercise of copyright. Consequently, the vast majority of countries

5 B Sherman and L Bently, The Making of Modern Intellectual Property Law: The British Experience 1760-1911 (Cambridge University Press, 1999) (For the definitive history of the emergence of registration systems in Britain and their significance in making intangible subject matter more 'manageable' as the object of property rights); C Dent, 'Registers of Artefacts of Creation - From the Late Medieval Period to the 19th Century' (2014) 3 Laws 239.

6 S van Gompel, Formalities in Copyright Law: An Analysis of their History, Rationales and Possible Future (Wolters Kluwer, 2011) (history of formalities in the UK, Continental Europe and the US); D Lipszyc, 'Historical Appearances and Disappearances of Formalities: From Berne to National Laws' in L Bently, U Suthersanen and P Torremans, Global Copyright: Three Hundred Years from the Statute of Anne, from 1709 to Cyberspace (Edward Elgar, 2010) 367 (history across Latin America).

7 Berne Convention for the Protection of Literary and Artistic Works, opened for signature 9 September 1886 (amended in 1914, 1928, 1948, 1967, 1971, and 1979) 1161 UNTS 3 ('Berne Convention'), 35 .

8 See respectively Art 9(1) of TRIPS (Marrakesh Agreement Establishing the World Trade Organization, opened for signature 15 April 1994, 1867 UNTS 3 (entered into force 1 January 1995), annex IC (Agreement on Trade-Related Aspects of Intellectual Property Right)) and Art 1(4) of the WIPO Copyright Treaty (World Intellectual Property Organization Copyright Treaty, opened for signature 20 December 1996, 36 ILM 65, entered into force 6 March 2002). 
do not impose mandatory formalities on their own nationals either. ${ }^{9}$ The Berne prohibition ensured that copyright moved from being an opt-in system to one of largely automatic protection.

Contemporary debates are therefore preoccupied with the scope of the Berne prohibition and the room to manoeuvre around it. ${ }^{10}$ By contrast, this chapter takes advantage of its counterfactual remit. Assuming we could have formalities today, would we want them? Its starting premise is a world without article 5(2) but having retained all the historical lessons around formalities. This speculative 'escape from history' is narrowly crafted, because of the obvious dangers of an abstract, functional or otherwise decontextualised approach to such a topic. ${ }^{11}$ The other drawback of a counterfactual approach is the difficulty in establishing causation - change this aspect of copyright to achieve that desired outcome - when there are so many moving parts. As we will see below, formalities proposals resonate with issues ranging from protectable subject matter to the duration of copyright protection. This chapter is therefore very much intended to be read alongside the other contributions in this volume.

Such a thought experiment is nevertheless valuable because the question of 'who owns what' looms large over copyright. Molly Van Houweling describes the problem as having three dimensions:

proliferation (how many works are subject to copyright ownership), distribution (how many different people own copyrights), and fragmentation (how many, what type, and what size of separatelyowned rights exist within each copyright bundle). As proliferation, distribution, and fragmentation increase, copyright becomes more atomistic. $^{12}$

9 S van Gompel, 'Les formalités sont mortes, vive les formalités! Copyright Formalities and the Reasons for their Decline in Nineteenth Century Europe' in R Deazley, M Kretschmer and L Bently (eds), Privilege and Property: Essays on the History of Copyright (OpenBook Publishers, 2010), $157 \mathrm{nl}$.

10 For the scope of the Berne Convention prohibition, see S Ricketson and J Ginsburg, International Copyright and Neighbouring Rights: The Berne Convention and Beyond, (Oxford University Press, $2^{\text {nd }}$ ed, 2006) 325. On the room to manoeuvre, see the contributions to the Symposium Issue 'Reform(aliz)ing Copyright for the Internet Age' (2013) 28 Berkeley Technology Law Journal.

11 On the dangers of universal theoretical models which ignore historical context, see P Knapp, 'Can Social Theory Escape from History? Views of History in Social Science' (1984) 23(1) History and Theory 34.

12 MS Van Houweling, 'Author Autonomy and Atomism in Copyright Law' (2010) 96 Virginia Law Review 549, 553. 
This fragmented patchwork of entitlements in turn generates greater search and transaction costs, especially since the legal and technological context within which copyright operates has undergone a paradigm shift.

In the past, a short term of copyright coupled with formalities and the natural restraints that arose in the hard copy world — significant costs in production and distribution - limited the public's innocent exposure to copyright infringement. With a functionally perpetual copyright duration, no formalities, and instant global distribution, matters have greatly changed. ${ }^{13}$

The principal problem that formalities address is that of inadequate information. Van Houweling illustrates this with the discovery of an old photograph, which qualifies as protectable subject matter:

It could be in the public domain because [it didn't satisfy previouslyapplicable mandatory formalities or because] its copyright has expired; or it could be under copyright, held by an unknown copyright holder. Without more information (or an applicable limitation like fair use), the only safe assumption is that all of those activities that implicate the exclusive rights granted by copyright ... are prohibited. ${ }^{14}$

Given the growing appetite for the reuse of content online, the lack of adequate information inhibits rights clearance efforts while also impeding the reuse of material that might already be in the public domain and freely available for repurposing. This in turn encourages either caution (to the point where rights clearance costs entirely prevents projects) or rampant infringement.

Such high information costs and the attendant ambiguity are all the more puzzling when we live in an information society. Technological developments directly address one of the primary motivations for article 5(2), which responded to the difficulties experienced by creators confronted with a daunting array of jurisdiction-specific formalities. However the 'pragmatic arguments that inspired the abolition of formalities from national and international copyright law have also largely evaporated in the digital age. Nowadays, registration and deposit can be organized much more efficiently and made applicable

13 W Patry, How to Fix Copyright (Oxford University Press, 2011) 204.

14 MS Van Houweling, 'Land Recording and Copyright Reform' (2013) 28 Berkeley Technology Law Journal 1497, 1498. 
to virtually any type of work' ${ }^{15}$ Revisiting the question of formalities is neither regressive nor backwards looking. According to Maria Pallante, the US Register of Copyrights, to 'address twenty-first century challenges we need twenty-first century solutions ... the question is not whether the rules of the nineteenth and early twentieth centuries should be reintroduced, but rather, whether new rules might serve the policy objectives of the digital age'. ${ }^{16}$

Against this backdrop, this chapter specifically considers whether mandatory or strongly incentivised registration would serve the public interest better than automatic copyright. To that end, section 2 defines formalities, and introduces the most common types historically associated with copyright law. The rationales for formalities are then mapped on to distinct public interest outcomes. Section 3 reviews the arguments both for and against the reintroduction of formalities. The concerns underlying article 5(2) of Berne would have to be addressed by any reform efforts. Bearing these in mind, section 4 contains the principal substantive contribution of this chapter. It outlines what a mandatory copyright registration system at the national level might look like. It draws inductively upon existing studies of voluntary copyright registration, and other IP and land registration systems. Section 5 concludes that, given the option, it would be irrational to continue to operate as we presently do.

\section{Formalities and the public interest}

\subsection{What are formalities?}

Broadly understood, formalities 'refer to the procedural mechanisms which are required for acquiring a valid copyright, such as registration, notice, deposit, or renewal procedures'. ${ }^{17}$ They are conditions independent of those substantive requirements relating to the creation of the work, such as the originality or fixation

\footnotetext{
15 van Gompel, above n 5, 263.

16 MA Pallante, 'The Curious Case of Copyright Formalities' (2013) 28 Berkeley Technology Law Journal 1415, 1416.

17 C Sprigman, 'Reform(aliz)ing Copyright' (2004) 57 Stanford Law Review 485, 487.
} 
requirements. ${ }^{18}$ Land law scholars further emphasise the distinction between substance and form, so that 'in law, a formality is a requirement that matters of substance must be put into a particular form (in order to have a specified legal effect)' with sanctions for non-compliance. ${ }^{19}$

Thus the article 5(2) prohibition encompasses 'everything which must be complied with in order to ensure that the rights of the author with regard to his work may come into existence' as well as prerequisites before the right can be exercised. ${ }^{20}$ However the prohibition is copyright-specific and does not extend to generally applicable rules of evidence and procedure. Finally, formalities have varied across jurisdictions, historical periods and categories of works. While there was a notice requirement for engravings, prints and photographs in some situations, there was an additional deposit requirement for literary works in others. ${ }^{21}$

\subsection{Types of formalities}

Certain copyright formalities have largely dropped away from contemporary debates. Examples would be a 'local manufacturing or working' requirement, which called for printing within a jurisdiction and favoured local labour interests, ${ }^{22}$ as well as opt-out formalities, whereby the right holder needs to expressly claim rights over certain uses of a work (e.g. producing translations) by way of a notice. ${ }^{23}$ The ones considered below remain relevant and have direct parallels with the other IP regimes, namely:

18 Mihály Ficsor, Guide to the Copyright and Related Rights Treaties Administered by WIPO and Glossary of Copyright and Related Terms (WIPO, 2003), [BC-5.7].

19 P Critchley, 'Taking Formalities Seriously' in S Bright and J Dewar (eds), Land Law: Themes and Perspectives (Oxford University Press, 1998) 507, 508.

20 J Ginsburg, 'The US Experience with Copyright Formalities: A Love-Hate Relationship' (2010) 33 Columbia Journal of Law and the Arts 311, 315-316.

21 van Gompel, above n 5, Ch 3.

22 Ginsburg, above n 19, 313. Ginsburg revisits opt-out formalities in the context of mass digitisation projects, arguing that a presumption to authorise digitisation and dissemination, unless the author actively opts out, would be incompatible with the Berne Convention. See JC Ginsburg, ‘Berne-Forbidden Formalities and Mass Digitization' (2016) 96 Boston University Law Review 101.

23 Exemplified by Art 10bis(1) of the Berne Convention, which permits the reproduction of articles on current events in the press or contained in broadcasts, unless rights over this content are expressly reserved. See M Senftleben, 'How to Overcome the Normal Exploitation Obstacle: Opt-Out Formalities, Embargo Periods, and the International Three-Step Test' (2014) (1) Berkeley Technology Law Journal Commentaries 1. 


\subsubsection{Registration}

Registration is a requirement common to patent, trademark and industrial design protection regimes, where the object of protection is identified within a publicly accessible register. ${ }^{24}$ The application also contains information regarding ownership and the priority date for protection. For copyright registries, additional details relate to the category of work (literary, musical, artistic etc.); its title; the date and place of publication; and details related to the payment of fees. ${ }^{25}$ For some IP regimes, public registration ${ }^{26}$ is unavoidable, being intrinsically linked to their normative foundations. Patent protection for example represents a bargain between the inventor and the public. New and useful technical information is disclosed within a publicly accessible register, in return for the grant of proprietary rights. ${ }^{27}$ For such systems, the question of what is protected has additional significance, but the question of who (i.e. ownership) has importance across all fields of proprietary entitlements. Property law:

is centrally concerned with coordinating multiple rights in the same asset and managing the information burden that property rights place on third parties ... Since property rights are enforceable in rem against third parties, anyone wishing to acquire or deal with a resource incurs information costs in discovering and measuring any private property rights that may be held in the resource. ${ }^{28}$

Registration facilitates both publicity and - when coupled with rigorous examination - trustworthiness. ${ }^{29}$

In turn, accessible ownership information improves the security of title and facilitates the transfer of proprietary interests (or licensing, in the case of IP) which makes for a more efficient marketplace. Registration

\footnotetext{
24 van Gompel, n 5, [2.1.1].

25 WIPO, Summary of the Responses to the Questionnaire for Survey on Copyright Registration and Deposit Systems, (WIPO, 2010) Part A - 8.

26 Public here has two connotations: both publicly managed, i.e. operated by the state, as well as publicly accessible, so the information is widely available.

27 R Burrell, 'Trade Mark Bureaucracies', in GB Dinwoodie and M Janis (eds), Trade Mark Law and Theory: A Handbook of Contemporary Research (Edward Elgar, 2008) 95, 96-97 (Querying whether trademark registration is therefore essential, given the incomplete and imperfect information associated with the register).

28 P O'Connor, 'The Extension of Land Registration Principles to New Property Rights in Environmental Goods' in M Dixon, Modern Studies in Property Law, Vol 5 (Hart, 2009) 363, 364. 29 M Ilmari Niemi 'The Public Trustworthiness of Land Registers in the Nordic Countries' in E Cooke (ed), Modern Studies in Property Law, Vol 1 (Hart, 2000) 329, 329.
} 
simplifies proof, reduces risk and streamlines transactions. ${ }^{30}$ To facilitate the comprehensiveness of ownership records, registration is therefore either mandatory ${ }^{31}$ or optional but incentivised via the provision of evidentiary or remedial advantages. ${ }^{32}$ This logic broadly applies to IP registration with some qualifications, as section 4 elaborates below.

\subsubsection{Renewal}

Once an IP registration is obtained, it requires renewal after a specified period in order to prolong protection up to the maximum term available. Trademark protection is available indefinitely, but requires periodic renewal every 10 years. ${ }^{33}$ To avail of the maximum 20-year term in patent law, maintenance fees must be paid, varying from an annual maintenance fee to one payable every three or four years. ${ }^{34}$ Historically, many copyright registration systems had a renewal requirement and the US is notable for having retained both mandatory registration and renewal until relatively recently. ${ }^{35}$ Under the Copyright Act of 1909, after an initial 28-year period of registered protection from the date of first publication, a second statutory term of 28 years was available upon applying for renewal. Without renewal, the work would enter the public domain. ${ }^{36}$ As a potential policy lever, the renewal process discourages the (re-)registration of commercially insignificant works. ${ }^{37}$ Research reviewing renewal data as a proxy for the author's desire to maintain protection concludes that less than 15 per cent of all US registered copyrights were being renewed after the initial term of protection across the 20th century. ${ }^{38}$ Renewal of copyright registration historically served a filtering function, with works which are no longer renewed passing into the public domain. ${ }^{39}$

30 P O'Connor, 'Registration of Title in England and Australia: A Theoretical and Comparative Analysis' in E Cooke (ed), Modern Studies in Property Law, Vol 2 (Hart, 2003) 81, 84.

31 For a review of the UK's transition to a mandatory, constitutive registration system i.e. title by registration, see E Cooke, The New Law of Land Registration (Hart, 2003).

32 For an overview of US land registration principles, see Van Houweling, above n 13.

33 WIPO Secretariat, Summary of Replies to the Questionnaire on Trade Mark Law and Practice (SCT/11/6), WIPO/STrad/INF/1 Rev (25 January 2010), 182-190.

34 WIPO, Intellectual Property Handbook: Policy, Law and Use (WIPO Publication No. 489(E), $2^{\text {nd }}$ ed, 2004), [2.82].

35 The history of US formalities is reviewed in Ginsburg, above n 19, 322-331; van Gompel, above $\mathrm{n} 5$, Ch 3 .

36 S 23 of the Copyright Act of 1909; 17 USC $\S 24$ (1947).

37 WM Landes and RA Posner, 'Indefinitely Renewable Copyright' (2003) 70 University of Chicago Law Review 471 (Advocating sufficiently high fees to encourage such weeding out).

38 Sprigman, above n 16, 519-521.

39 Kahle $v$ Gonzales, 487 F3d 697, 699 ( $9^{\text {th }}$ Cir, 2007). 


\subsubsection{Recordation}

Recordation or recordal requires that information about transfers, or the creation of related property interests (such as charges) be made publicly available. The 'key to an effective recording system is its completeness, and ideally all links in a chain of title should be placed on record' ${ }^{40}$ Recordation complements a mandatory registration system that provides the initial information identifying the copyrighted work, first ownership and the commencement of the copyright term. Alternatively this information could be submitted alongside that relating to the transfer of ownership. ${ }^{41}$ According to Pallante:

[the] recordation system is extremely important because it has the potential to connect registration information ... to the ongoing chain of commerce for a particular work (which could span decades). It provides information regarding who has acquired what exclusive rights and whether and how copyright ownership has changed hands. ${ }^{42}$

Recordal has significant effects - it generally constitutes notice to the world at large of the facts recorded, and the transferee receives priority over (i) subsequent conflicting transfers or interests, (ii) as well as (potentially) against prior but unrecorded interests, so long as there was no actual notice of their existence. ${ }^{43}$ Recordation must usually occur within a specified time window to be effective. ${ }^{44}$

\subsubsection{Notice}

Notices are used in IP regimes to signal the protected status of subject matter - the familiar ${ }^{\circledR}$ or ${ }^{\mathrm{TM}}$ symbols associated with trademark law, or the (C) symbol in association with the first owner's name and year of publication are fairly ubiquitous. In general the adoption of

40 A Latman, The Recordation of Copyright Assignments and Licenses (US Copyright Office, Study No 19, 1998) 124-125.

41 JC Ginsburg, “"With Untired Spirits and Formal Constancy": Berne Compatibility of Formal Declaratory Measures to Enhance Copyright Title-Searching' (2013) 28(3) Berkeley Technology Law Journal 1583.

42 Statement of Maria A Pallante, Register of Copyrights and Director of the United States Copyright Office, 'Oversight of the U.S. Copyright Office', Hearing Before the Subcommittee on Courts, Intellectual Property, and the Internet, Committee on the Judiciary United States House of Representatives (18 September 2014).

43 For the effects of 'race', 'notice' and 'race-notice' regimes, see A Green et al, Improving Copyright Information Management: An Investigation of Options and Areas for Further Research (Stanford Law School, Law and Policy Lab 2014) 20.

44 van Gompel, above n 5, [2.1.3]. 
such notices is entirely voluntary, ${ }^{45}$ with legal rules sanctioning only their misleading use ${ }^{46}$ However legal consequences are possible, as US history illustrates. The Copyright Acts of 1790, 1802 and the 1831-1905 Acts all required the record of registration to be published - initially in newspapers and subsequently in a specified location on the work (the title page). ${ }^{47}$ Failure to comply initially resulted in exclusion from protection and subsequently publication without notice shifted the work into the public domain. This requirement has been diluted over time: and today the only significant consequence is that the defence of innocent infringement may be available where a published work lacks a copyright notice. ${ }^{48}$ The interesting aspect of the US copyright notice requirement is that from 1909 it became detached from the registration requirement and operated as a standalone formality. Therefore, a standalone notice requirement coupled with an effective recordation register - both being obligatory - might ensure that up-to-date ownership as well as term information was provided to the public.

\subsubsection{Deposit}

Depositing one or more copies of the work for which protection is desired has been a feature of copyright legislation since at least the Statute of Anne:

Those who printed books were obliged to deposit nine copies with the Stationers Company for distribution to the Royal Library, six Universities, Sion College in London and the Faculty of Advocates in Edinburgh; failure to do so made not only the printer but the 'proprietor' and bookseller liable to a fine ... The obligation was collateral in the sense that deposit was not an express condition of protection under the Statute. ${ }^{49}$

45 A notable counter-example is the obligatory requirement to signal protected geographical indication status in the EU. See D Gangjee, 'Proving Provenance: Geographical Indication Certification and its Ambiguities' (2017) World Development (forthcoming).

46 van Gompel, above n 5, [2.1.5].

47 For a very convenient history in tabular form, see Ginsburg, n 19, 326-327.

48 A Reid, 'Claiming the Copyright' (2016) 34 Yale Law and Policy Review 425 (advocating a return to an effective notice requirement as a means of claiming copyright, by proposing an 'innocent infringer' defence in the absence of such claiming).

49 W Cornish, 'The Statute of Anne 1709-10: Its Historical Setting' in L Bently, U Suthersanen and P Torremans, Global Copyright: Three Hundred Years from the Statute of Anne, from 1709 to Cyberspace (Edward Elgar, 2010) 14, 23. 
Here the public interest lay in increasing collections in public libraries and developing cultural repositories. A WIPO survey indicates that a deposit requirement has been widely adopted. ${ }^{50}$ However over time, it has become detached from the question of copyright subsistence. The penalty for non-compliance is usually a fine and not the forfeiture of copyright. ${ }^{51}$

The WIPO survey also documents the various functions served by a deposit requirement: ${ }^{52}$

- Proof of both publication and (potentially) the date of creation

- Proof of ownership

- Supporting research and development by making publications available

- Preservation of cultural heritage (archiving) along with the publication of a national bibliography

- Statistical information generated from deposited works.

Beyond these functions, deposit also assists in the process of identifying the intangible object of protection. In the absence of representative registration, a deposit of the physical embodiment of the work - the actual book itself - was the exemplar of the intangible subject matter. ${ }^{53}$

The formalities identified above can be further classified in terms of their legal nature and effects. Stef van Gompel has developed a helpful taxonomy, ${ }^{54}$ differentiating between mandatory and voluntary formalities while going on to consider further divisions based on legal effects: (i) 'constitutive', operating as necessary preconditions for protection; (ii) 'maintenance' focused, such as renewal; and (iii) 'declaratory', which are required for giving effect to rights previously recognised. We might also distinguish between the 'old-style' formalities discussed above and 'new-style' formalities, which embrace digital technology to facilitate ownership tracing. ${ }^{55}$

\footnotetext{
50 WIPO, Summary of the Responses to the Questionnaire for Survey on Copyright Registration and Deposit Systems, (WIPO, 2010), Part B - 1.

51 Ibid.

52 Ibid 2.

53 See Section 4, below.

54 van Gompel, above n 5, [2.2]-[2.2.4].

55 van Gompel, 'Copyright Formalities in the Internet Age: Filters of Protection or Facilitators of Licensing' (2013) 28(3) Berkeley Technology Law Journal 1425, 1435.
} 
This would include private sector digital repositories of rights management information and metadata associated with digital works, which have both benefits and drawbacks. ${ }^{56}$ Alternatively, Christopher Sprigman has described new-style formalities as Berne-compliant 'nudges' to provide ownership information, by offering attractive remedial options for doing so. ${ }^{57}$

\subsection{Correlating formalities with public interest(s)}

The public interest features frequently in copyright (and broader IP) doctrine and debates, either to advance proposals for reform or to serve as the baseline against which to assess new developments. ${ }^{58}$ At its core, the grant of private proprietary rights over intangibles is conventionally understood to promote the public interest, based on consequential reasoning. ${ }^{59}$ However the very appeal of this term - its capaciousness - is also its weakness. It has been considered vague, is difficult to measure, has been used inconsistently by different writers and many of its concepts are considered indistinguishable from morality. ${ }^{60}$ Another major concern, which is nicely illustrated in the copyright context, is the difficulty in identifying a homogenous collective interest. What happens when the interests of authors/ creators and the general public, or that of creators and those who invest in or distribute creative works diverge? Or if one of these groups claims to speak in the name of all?

However neither of these concerns is insurmountable. Drawing on the public interest(s) as a reference point for rethinking copyright remains compelling for three reasons.$^{61}$ First, alongside equally resonant terms like justice and freedom, the public interest functions as a normative

56 See Section 4, below.

57 CJ Sprigman, 'Berne's Vanishing Ban on Formalities' (2013) 28(3) Berkeley Technology Law Journal 1565, 1566-1567.

58 S Siy, 'Two Halves of the Copyright Bargain: Defining the Public Interest in Copyright' 31 Cardozo Arts \& Entertainment Law Journal 683; PA Jaszi, 'Goodbye to All That - A Reluctant (and Perhaps Premature) Adieu to Constitutionally-Grounded Discourse of Public Interest in Copyright Law' (1997) 29 Vanderbilt Journal of Transnational Law 595; Washington Declaration on Intellectual Property and the Public Interest (2011).

59 R Merges, Justifying Intellectual Property (Harvard University Press, 2011) 3.

60 See B Bozeman, Public Values and Public Interest: Counterbalancing Economic Individualism (Georgetown University Press, 2007) 83-99.

61 See Rebecca Giblin and Kimberlee Weatherall, 'If we redesigned copyright from scratch, what might it look like?', this volume. 
ideal, creating the space to debate the political morality of legislative measures. It can also be particularised, having specific meanings within a defined context - here, copyright law in the early 21 st century, with its attendant international constraints, encoded assumptions regarding creation and distribution as well as economic and technological context. Second, it is the antidote to pure self-interest or divisive group politics. It encourages a broader understanding of social relations and provides the language for resisting the marketisation of state functions, a utopian vision of markets and a preference for private ordering.$^{62}$ Following on from this, it aligns with pluralistic copyright theorising which acknowledges norms in addition to those identified by a consequentialist approach which prioritises economic efficiency to maximise public welfare.$^{63}$ The third reason builds on the second. As a normative counterweight to reductive economic individualism, the public interest 'may be presumed to be what [people] would choose if they saw clearly, thought rationally, acted disinterestedly and benevolently'. ${ }^{64}$ So a copyright system designed in the public interest would result, as discussed by Giblin and Weatherall in their introduction, if people chose from behind the 'veil of ignorance'65 while also having in mind both market as well as non-market values (e.g. facilitating democratic deliberation) when making this choice.

With this in mind, what purposes do formalities serve and how does this align with the public interest? A helpful first move is to disaggregate the category of formalities. While formalities serve an array of distinct goals, two are prominent in contemporary debates. ${ }^{66}$ The first is the provision of reliable information regarding the ownership of copyright works. ${ }^{67}$ Thus registration, notice and recordation all serve to ensure

62 LD Brown and LR Jacobs, The Private Abuse of the Public Interest: Market Myths and Policy Muddles (University of Chicago Press, 2008) 2.

63 The literature is reviewed in O Bracha and T Syed, 'Beyond Efficiency: ConsequenceSensitive Theories of Copyright' (2014) 29 Berkley Technology Law Journal 229.

64 W Lippmann, cited in Bozeman, above n 59, 83. Bozeman, at 17, provides an alternative conception emphasising the inter-generational, social dimension: An ideal public interest refers to those outcomes best serving the long-run survival and well-being of a social collective construed as a "public".

65 See Rebecca Giblin and Kim Weatherall, 'If we redesigned copyright from scratch, what might it look like?', this volume.

66 As reflected in the choice of title: 'Filters of Protection of Facilitators of Licensing'. See van Gompel, above n 54.

67 Ibid 1443. See also Pamela Samuelson et al, 'The Copyright Principles Project: Directions for Reform' (2010) 25 Berkeley Technology Law Journal 1175, 1186 (pointing out that current incentives for registration in the US have not guaranteed an informative register). 
that owners are easier to trace, which facilitates rights clearance transactions. Assuming that we are not challenging the entire edifice of copyright and a regime of author-protective proprietary rights is considered appropriate, the provision of better quality information regarding ownership is clearly in the public interest. The benefits were previously summarised in section 2.2(a), when considering the rationale for land registration systems. In contemporary copyright scholarship new-style formalities, such as incentivising the provision of publicly accessible rights management information, are thought to have similar potential. ${ }^{68}$

The second major goal is the enhancement of the public domain, also referred to as the filtering function of formalities. ${ }^{69}$ For works which are protected, accessible information about subsistence would enable accurate predictions about when they will enter the public domain, removing much of the present ambiguity. More importantly, constitutive formalities act as an entry level barrier into copyright protection, by requiring positive acts on the part of those seeking protection. Non-compliance with formalities is likely to result in more works entering the public domain. ${ }^{70} \mathrm{~A}$ burgeoning public domain that is regularly replenished has several advantages, which are considered to be in the public interest. ${ }^{71}$ It facilitates a vibrant cultural commons, which is considered the wellspring for future creative endeavours; ${ }^{72}$ it makes a viable public sphere possible, as envisaged by Jürgen Habermas, with the capacity to critique the state since political discourse can draw on the matrix of cultural production; $;^{73}$ and despite no IP protection - generates considerable economic value. ${ }^{74}$

\footnotetext{
68 van Gompel, above n 54, 1443.

69 WIPO, Copyright Registration and Documentation Systems, WIPO: <www.wipo.int/ copyright/en/activities/copyright_registration/> ('Registration can also help to delimit the public domain, and consequently facilitate access to creative content for which no authorization from the right owner is needed'); BA Greenberg, 'More Than Just a Formality: Instant Authorship and Copyright's Opt-Out Future in the Digital Age' (2012) 59 UCLA Law Review 1028, 10431044; Ginsburg, above n 19, 312-313; Sprigman, above n 16, 487.

70 van Gompel, above n 54, 1433.

71 G Davies, 'The Public Interest in the Public Domain' in C Waelde and H MacQueen, Intellectual Property: The Many Faces of the Public Domain (Edward Elgar, 2007) 86.

72 J Boyle, The Public Domain: Enclosing the Commons of the Mind (Yale University Press, 2008).

73 M Rose, 'Nine-tenths of the Law: The English Copyright Debate and the Rhetoric of the Public Domain', 66 Law \& Contemporary Problems, 75.

74 Dussolier, above n 2, 19-20; K Erickson et al, Copyright and the Value of the Public Domain (UK IPO, 2015).
} 
However the counterpoint to this is that the public interest in supporting authors/creators could be deprioritised in a system which adopts constitutive formalities. Thus 'formalities predicate to the existence or enforcement of copyright can serve to shield large copyright owners who routinely comply with formalities from the infringement claims of smaller copyright owners, particularly individual authors, who may lack the information or resources systematically to register and deposit their works' ${ }^{75}$ Here the balancing of competing public interests, via appropriate institutional design choices, is essential. Having mapped the main categories of formalities and identified the public interests at stake, it is possible to assess more detailed arguments for and against their adoption.

\section{Arguments for and against formalities}

Today the reintroduction or adaptation of formalities is under serious consideration. Formalities have found favourable mention in policy documents addressing copyright's more serious deficiencies. ${ }^{76}$ The problem of orphan works is also helping to focus minds on their potential. Orphan work is 'a term used to describe the situation where the owner of a copyrighted work cannot be identified and located by someone who wishes to make use of the work in a manner that requires permission of the copyright owner' ${ }^{77}$ Tracing difficulties vary across categories of works. A study for the European Commission estimates that 13 per cent of in-copyright books, 90 per cent of photographs in museum collections and 129,000 films in film archives are orphaned. ${ }^{78}$ Where authors are unidentifiable or cannot be traced, the risk of litigation is enough to deter libraries, archives, publishers and filmmakers from making use of the work.

75 Ginsburg, above n 19, 313.

76 UK IPO, (C) The Way Ahead: A Strategy for Copyright in the Digital Age (2009), [108]-[109]; Samuelson et al, above n 66, Part III, Recommendations 1 and 2; Report of the Comité des Sages, The New Renaissance (Brussels, 10 January 2011) 5, 18-19, 20-21; Australian Law Reform Commission, 'Copyright and the Digital Economy' (Discussion Paper 79, May 2013), 265.

77 US Copyright Office, Report on Orphan Works: A Report of the Register of Copyrights (2006) 15. To similar effect, see Art 2 of Directive 2012/28/EU of the European Parliament and of the Council of 25 October 2012 on Certain Permitted Uses of Orphan Works, [2012] OJ L 299, 5.

78 A Vuopala, Assessment of the Orphan Works Issue and Costs for Rights Clearance (European Commission, DG Information Society and Media Unit E4: Access to Information, May 2010) 4-5. 
Even attempting to trace right holders is time-consuming and expensive. The BBC's Archive Trial reported that checking 1,000 hours of the most straightforward content - factual programming - for rights clearance cost them 6,500 person hours. Extrapolating from available figures on clearance and the associated costs, the UK Intellectual Property Office has estimated that it would take between $£ 6.6$ billion and $£ 8.4$ billion to fully search and clear the content of the $\mathrm{BBC}$ archives and the British Library. ${ }^{79}$ The orphan works problem is a direct consequence of 'informal' copyright and the insufficiency of ownership information. ${ }^{80}$ The result is stalled digitisation projects, endemic uncertainty and the regrettable under-utilisation of considerable cultural resources.

These difficulties have given rise to a body of scholarship exploring the benefits of technologically upgraded and sensitively adapted variants of historic formalities. With the notable exception of van Gompel's detailed historical and comparative work, the majority of these scholars draw on US experiences with formalities, which remained central to copyright protection until 1976, before diminishing in $1989 .{ }^{81} \mathrm{~A}$ high-altitude survey of arguments in support of formalities would look something like this: a copyright register reduces search and tracing costs. Yet historical experience suggests registration was an unacceptable burden for authors, especially those seeking international copyright protection. The subsequent abandonment of formalities resulted in an inefficient and opaque property regime, more 'mud' than 'crystals' when it comes to defining entitlements. Present day digital technologies have made the Library of Alexandria dream of universally accessible knowledge appear tantalisingly within reach. Digital technology, in the form of cheap, effective e-filing and digital deposits, coupled with vastly improved search capabilities,

79 UK IPO Consultation, Copyright Works: Seeking the Lost (UK IPO, 2014) 65-70.

80 DR Hansen, 'Orphan Works: Causes of the Problem' (White Paper No 3, Berkeley Digital Library Copyright Project, 2012) 11.

81 See Landes and Posner, above n 36; Sprigman, above n 16; J Gibson, 'Once and Future Copyright' (2005) 81 Notre Dame Law Review 167; D Fagundes, 'Crystals in the Public Domain' (2009) 50 Boston College Law Review 139; Samuelson et al, above n 66; Patry, above n 12, 203-209; van Gompel, above n 5. Digitally enhanced formalities also feature in the work of Lawrence Lessig: see e.g. The Future of Ideas: The Fate of the Commons in a Connected World (Random House, 2001) 251-252 and Remix: Making Art and Commerce Thrive in the Hybrid Economy (Bloomsbury, 2008) 260-265. 
also means that formalities need not be cumbersome or expensive. ${ }^{82}$ Non-compliance also need not deprive an author of copyright. Instead a pause button might be pressed: via a moratorium on infringement claims until registration, or limits on the scope of available remedies. Formalities would therefore help channel more works into the public domain as well as facilitate rights clearance, through the provision of accurate, periodically refreshed information. Registration would additionally generate reliable 'big data' on the culture industries, while digital deposits would function as a cultural repository.

There is, however, another side to this story, since formalities were abandoned for good reasons. The first objection relates to the incompatibility of formalities with the underlying conceptual and normative commitments of copyright regimes in droit d'auteur systems. Central to this argument is a natural rights-based justification - whether Lockean or Hegelian - which privileges the act of creation itself. ${ }^{83}$ As Ginsburg puts it, if 'copyright is born with the work, then no further state action should be necessary to confer the right; the sole relevant act is the work's creation' ${ }^{84}$ Mandatory formalities fashioned to achieve instrumental outcomes, such as the public availability of better quality information, should not be permitted to trump these natural rights foundations.

This objection has been thoroughly investigated by van Gompel and his conclusion is both nuanced and convincing. Towards the end of the 19th century:

there was a growing consensus that the existence of copyright should not be subject to formalities and that failure to comply with formalities should never be the occasion of a loss of copyright ... At the same time, it was acknowledged that the protection of literary and artistic works was not unconditional, but should always be established in accordance with the public interest and societal order. ${ }^{85}$

82 For interesting insights into bureaucratic registration systems as a form of technology, see Dent, above $\mathrm{n} 4$.

83 Daniel Gervais and Dashiell Renaud, 'The Future of United States Copyright Formalities: Why We Should Prioritize Recordation, and How To Do It' (2013) 28(3) Berkeley Technology Law Journal 1459, 1463.

84 JC Ginsburg, 'A Tale of Two Copyrights: Literary Property in Revolutionary France and America' (1990) 64 Tulane Law Review 991, 994.

85 van Gompel, above n 5, [3.3.2.1]. 
While natural rights foundations were in tension with constitutive formalities relating to the existence or acquisition of proprietary rights, the exercise of these rights could be regulated in the public interest. Meanwhile the Berne prohibition was based on practical difficulties faced by authors seeking to secure copyright protection abroad and did not arise from epistemological or justificatory divergences. ${ }^{86}$

Turning to these practical impediments, the first relates to the difficulties in satisfying formalities requirements and the second relates to the harsh consequences for not complying with them. For the former, historic experience indicates:

the failure [might not] be attributable to the author (for example, if the formality could also be legally complied with by the publisher), if a formality was not fulfilled because of the intricacy and costs involved (for instance, if the facilities where the formality must be completed were located too far away) or if it concerned mere technical failures (for example, innocent mistakes or late submissions of applications). In the nineteenth century, it was not uncommon for authors to lose protection as a result of any of these practicalities. ${ }^{87}$

For the latter, Ginsburg suggests that the US experience is more of a cautionary tale than an inspirational template. Disproportionate penalties for non-compliance are manifestly unfair, since:

not all those who fail to fulfil these obligations do so because they do not care about their works. Some lose track; some are ignorant of the obligation, particularly if they reside in foreign countries which do not impose formalities; some may find the fees prohibitive. ${ }^{88}$

A third concern is that formalities - and registration in particular will favour commercial copyright owners as well as repeat players. It has been argued that the US regime, which incentivises formalities, 'privileges the interests of repeat, sophisticated rights holders, often at the expense of smaller, less sophisticated creators' ${ }^{89}$ Nina Elkin-Koren points out that the hypothetical calculus underpinning formalities - estimating whether a work is sufficiently valuable to protect is seriously flawed, since creators may not be able to assess the value

\footnotetext{
86 van Gompel, above n 8, 158.

87 Ibid 185.

88 Ginsburg, above n 19, 342.

89 J Tehranian, 'The Emperor Has No Copyright: Registration, Cultural Hierarchy, and the Myth of Copyright Militancy' (2009) 24 Berkeley Technology Law Journal 1399, 1399.
} 
of their works ex ante. The regime might be biased towards repeat players in the content industry and disadvantage individual creators. ${ }^{90}$ The resulting danger is that individuals who may occasionally wish to exercise their copyright will lose out. It 'seems unfair for someone to capture sensational news on a photo, post it online to share it with friends, and then see her photo being (commercially) exploited by various kinds of news services'. ${ }^{91}$

These are legitimate concerns that should be reflected in the design of any reform proposals. However recent empirical research on voluntary US copyright registration suggests that there is a roughly even split between individuals and firms in terms of overall registrations (51.9 per cent by firms and 48.1 per cent by individuals). Variations emerge along the lines of categories of works.

Nearly two thirds of Sound Recording, Text, and Visual Material are registered by firms. Dramatic Work, Music, and Sound Recording and Music are predominately registered by individuals. The remainder, Sound Recording and Text, are relatively evenly split between individuals and firms. These percentages are consistent with notions of how accessible markets are to individuals. ${ }^{92}$

Current practice therefore suggests that individuals are willing to register for certain categories of works.

The fourth concern follows directly on from the narrowness of a system focusing on commercially motivated repeat players, at the cost of user-generated content and social production. The paradigm for vast swathes of cultural creation and distribution has shifted. Apart from lowering transaction costs, a digital network 'brings about more fundamental changes, transforming the way we create, disseminate, and consume cultural works' ${ }^{\prime}{ }^{93}$ Individuals are both authors and users of existing works since '[w]orks in digital format can be easily mixed and matched, cut and pasted, or edited and remixed. The ease of changing and adapting enables users to appropriate cultural icons to express new meanings and to aggregate existing works into new

90 Nina Elkin-Koren, 'Can Formalities Save the Public Domain' (2013) 28(3) Berkeley Technology Law Journal 1537, 1543.

91 van Gompel, above n 54, 1442.

92 D Oliar, N Pattison, K Ross Powell, ‘Copyright Registrations: Who, What, When, Where and Why' (2014) 92 Texas Law Review 2211, 2226.

93 Elkin-Koren, above n 89, 1545. 
content' ${ }^{94}$ Should bloggers or online parodists be forced down the path of formalities? And how should collaboratively produced works such as Wikipedia be incorporated into any system of formalities? ${ }^{95}$

Finally, in a mandatory formalities regime which discourages individual, non-professional creators, who ultimately harvests the benefits of creative labour in a digital ecosystem? One suggested answer is online intermediaries, who would like their content inputs to be "free" (in both cost and repurposing senses) while they need their outputs to be appropriable if they want to receive a return on investment for their innovations'.$^{96}$ Alternatively, if the expectation is that everyone can opt-in to formalities, by setting the qualification thresholds low enough, we are then faced with the problem of scale. There will simply be too many works to keep up with formalities and for many creative professionals who make use of the internet, registering each tweet or photograph will quickly add up, making even reasonably priced registration prohibitively expensive. ${ }^{97}$ However Ginsburg suggests a response to this in the form of a combination of an annual registration account into which a discounted annual blanket fee could be paid, which covers one year's output for a specified type of work. ${ }^{98}$

The fifth concern is that we should we careful what we wish for. A perfect and accessible record of ownership would encourage rights clearance as a default position. We would be channelled towards obtaining licences for uses which might be de minimis or otherwise permitted under copyright exceptions or limitations. ${ }^{99}$ There is some evidence to support this from current automated systems like Google's Content ID, most conspicuously used by YouTube. Once a digital

\section{Ibid.}

95 The question is raised by Elkin-Koren, above n 89, 1545. However such large scale, multiauthor and constantly evolving collaborative works are also difficult to accommodate within the present copyright regime: see D Simone, 'Copyright or Copyleft? Wikipedia as a Turning Point for Authorship’ (2014) 25 Kings Law Journal 102.

96 MS O'Connor, 'Creators, Innovators and Appropriation Mechanisms' (2015) 22 George Mason Law Review 973, 974. However this unevenness of bargaining power is problematic under the present copyright arrangements as well. For a sophisticated critique of contemporary network capitalism and attempts to exploit immaterial labour in the context of free and open source software, see A Barron, 'Free Software Production as Critical Social Practice' (2013) 42 Economy and Society 597.

97 Greenberg, above n 68, 1046-1056.

98 Ginsburg, above n 19, 346.

99 Elkin-Koren, above n 89, 1561. 
sample of the protected work has been electronically deposited, it is used as the template against which to check for copies, via automated search algorithms, when new work is submitted. If a match is found, the 'registered' copyright owner can choose to mute audio that matches their music, block a whole video from being viewed, monetise the video by running ads against it or track the video's viewership statistics. ${ }^{100}$ Without prior human review and involvement, the system is susceptible to false positives and accidental matches. It also lacks the ability to qualitatively assess the amount of a work that has been used, making the automated response potentially disproportionate to any unauthorised use. ${ }^{101}$

There is an additional reason to query whether better quality information will reduce transaction costs. Tracing costs are only a part of the problem. Acquiring a license also involves the cost of locating the owners, contacting them, negotiating a license, and paying a license fee $^{\prime}{ }^{102}$ While the introduction of formalities cannot directly address these costs, recent developments such as the UK's Copyright Hub have the potential to do so. ${ }^{103}$ The Hub was first envisioned as a Digital Copyright Exchange in the Hargreaves Review ${ }^{104}$ and further developed in collaboration with representatives from UK creative industries (music, publishing, audiovisual, images) as well as two affected sectors (educational institutions and archives/libraries/museums). ${ }^{105}$ One of the envisaged outcomes for this industry-backed Hub is to establish a marketplace for rights and provide streamlined licensing solutions. It will cater for high-volume, low-value transactions with otherwise low processing costs, such as shops that want to play music or documentary filmmakers who want to use an archive clip. A related purpose of the Hub is to develop and distribute open technologies for the benefit of copyright licensing industries in general. The Hub was officially launched in July 2015 and its operations will no doubt be closely followed.

100 See 'How Content ID works' at <support.google.com/youtube/answer/2797370?hl=en-GB>. 101 B Boroughf, 'The Next Great YouTube: Improving Content ID to Foster Creativity, Cooperation, and Fair Compensation' (2015) 25 Albany Law Journal of Science and Technology 95. 102 Elkin-Koren, above n 89, 1545.

103 See <www.copyrightdoneright.org/> and <www.copyrighthub.org/>.

104 I Hargreaves, Digital Opportunity: A Review of Intellectual Property and Growth (Independent Report for the UK IPO, May 2011).

105 R Hooper and R Lynch, Copyright Works: Streamlining Copyright Licensing for the Digital Age (Independent Report for the UK IPO, July 2012). 
While this section has set out a compendium of the major concerns, there will inevitably be others. ${ }^{106}$ The challenge is to address them in any proposed reforms to formalities, by drawing on these teachings when determining the point of time in the life cycle of a work at which formalities become necessary, by making them as convenient and as efficient as possible in both design as well as implementation and by proportionately tempering the consequences of non-compliance.

\section{Reconsidering registration}

With a better sense of the categories of copyright formalities, their functions and the reasons for abandoning them, it is time to re-evaluate registration - arguably the defining formality of modern intellectual property law. If we could impose some degree of mandatory registration for both national authors and foreigners, would it make sense to do so today? This requires us to confront a series of questions relating to the nature of a copyright register and its effects, which would be applicable to both mandatory and voluntary registers so the exercise is not entirely hypothetical. There is a growing interest in making existing voluntary registration systems work better. ${ }^{107}$ What follows is necessarily selective, but addresses some of the fundamentals.

\subsection{Registration infrastructure: e-filing}

Any copyright registration system needs to be easy to use, economical and efficient in terms of processing information. Electronic registration is the obvious solution. Here the European Union Intellectual Property Office (EUIPO, formerly known as OHIM) ${ }^{108}$ is an acknowledged leader. The success of its unitary trademark and designs registries, both in terms of application volumes and processing speeds, is attributed to the significant financial investment in e-business and e-filing systems which entered a new phase in 2002. The move towards a paperless

\footnotetext{
106 See generally Elkin-Koren, above n 89, who considers the significant role of digital megaplatforms as well as private initiatives as alternative information providers; see also Greenberg, above $\mathrm{n} 68$, who raises an interesting epistemological issue: Will a registration system perpetuate a 'high art v low art' hierarchy of aesthetics? Paintings might be registrable via digital deposit but what about performance art?

107 The WIPO Survey (see WIPO, Summary of the Responses to the Questionnaire for Survey on Copyright Registration and Deposit Systems, (WIPO, 2010)) arose in response to this interest.

108 See <euipo.europa.eu/ohimportal/en/>.
} 
system included 'electronic filing ... electronic communication and e-payment, online banking services and tools for examining and tracking the progress of registration online' ${ }^{109}$ They range from online options for renewal, recording changes in ownership and filing notices of opposition to pre-application tools like the Goods and Services Builder, helping an applicant to determine which goods and services they would need to apply for. ${ }^{110}$ These investments have been well received: in trademarks for example, 98 per cent of applications in 2014 were submitted via e-filing. ${ }^{111}$

By contrast, WIPO's 2011 Survey revealed that of the 48 respondents having copyright registration systems, less than half (46 per cent) had search facilities, 84 per cent had no publicly accessible online search facilities and only 21 per cent provided for digital storage of registered works, ${ }^{112}$ and while access to registered works is granted, it is often a long, costly and bureaucratic process. Present day copyright registries seem to prioritise the evidentiary advantages of registration for the applicant/copyright holder, ${ }^{113}$ instead of functioning as an informative resource for the public. However there are some exceptions. The US Copyright Registry's eCO Registration System, launched in 2008, allows for the electronic registration of 'basic claims', which include 'literary works, visual arts works, performing arts works, sound recordings, motion pictures, single serial issues, groups of serial issues and groups of newspaper/newsletter issues' ${ }^{114}$ The entire process can be completed electronically, from filing the application to securely paying the fees (including the option of advance deposit accounts for frequent users) and submitting an electronic deposit of the work in prescribed file formats. ${ }^{115}$ Fees are comparatively modest at the time

109 OHIM, Strategic Plan 2011/2015 (2011) 13.

110 See <euipo.europa.eu/ohimportal/en/online-services>.

111 OHIM, Annual Report 2014, 14.

112 Victor Vazquez, 'Second Survey on Voluntary Registration and Deposit Systems' (14 October 2011, Geneva), <www.wipo.int/export/sites/www/meetings/en/2011/wipo_cr_doc_ge_11/pdf/ vazquez.pdf $>$.

113 This would include a rebuttable presumption of authorship, ownership, or the date of creation as found on the register. See the WIPO Survey: WIPO, Summary of the Responses to the Questionnaire for Survey on Copyright Registration and Deposit Systems, (WIPO, 2010), 5.

114 See < copyright.gov/eco/>.

115 For an overview of the registration process, see US Copyright Office, Compendium of US Copyright Office Practice ( $3^{\text {rd }}$ ed, 22 Dec 2014) Chapter 200. 
of writing, with an online Single Application (one author, one work) being $\$ 35$ and an online Standard Application (for all other filings) costing $\$ 55$. Paper based registrations cost $\$ 85 .{ }^{116}$

While eCO is primarily geared towards the registration of claims, the US Copyright Registry has electronic records of registration, renewals and recordation from 1978 onwards, which are electronically searchable via the online records catalogue. ${ }^{117}$ The Digitisation and Public Access Project, currently underway, is converting the vast card catalogue backlog into electronic formats and will provide web access to the pre-1978 Copyright records when complete. ${ }^{118}$ Based on a request by member states from Latin America, WIPO has also developed the GDA (Gestión de Derecho de Autor) system to assist copyright offices in automating the administration and management of copyright registration data. ${ }^{119}$ The system is built using open source software and designed for use by optional, publicly managed copyright registries. By this stage there is certainly operational experience when it comes to establishing electronic registries ${ }^{120}$ as well as digitising prior registration records.

Apart from existing public registries, '[p]rivate copyright registration and documentation systems around the world arguably constitute the largest pool of information concerning copyright and related rights' ${ }^{121}$ Michael Carroll identifies three groups of such entities: (1) registries administered by organisations that either own rights under copyright or related rights, or act as transactional agents for right holders - for example, Collective Management Organisations (CMOs); ${ }^{122}$ (2) third party registries or copyright documentation services that do not solely rely upon input from right holders to gather information about works and their owners (e.g. YouTube's ContentID registry);

\footnotetext{
116 See $<$ copyright.gov/about/fees.html $>$.

117 See $<$ www.copyright.gov/records/>.

118 See $<$ www.copyright.gov/digitization/ $>$.

119 See $<$ www.wipo.int/copyright/en/initiatives/gda.html $>$.

120 WIPO provides e-filing for its international registration regimes under the Patent Cooperation Treaty, the Madrid System for the International Registration of Trade Marks and the Hague System for the International Registration of Designs. See <www.wipo.int/services/en/>.

121 M Ricolfi et al, Survey of Private Copyright Documentation Systems and Practices (WIPO, 2011) 4 .

122 CB Graber, 'Is There Potential for Collective Rights Management at the Global Level? Perspectives of a New Global Constitutionalism in the Creative Sector' in D Gervais and S Frankel (eds), The Evolution and Equilibrium of Copyright in the Digital Age (Cambridge University Press, 2014) 241, 244.
} 
and (3) organisations that compete in parallel with public registration systems to provide right holders with copyright documentation services, such as notice (e.g. watermarking), registration, or deposit. ${ }^{123}$ These systems - more specifically (1) and (3) - are of interest for two reasons.

First, with comprehensiveness in mind, a publicly managed copyright registration system should be connected to these private registries to increase the coverage of records. However at present, 'the majority of copyright registering bodies are not interconnected to other copyright data systems provided either by public or private entities'. ${ }^{124}$ Many public registries have not yet made the transition to electronic systems, while for those that have done so compatibility and interoperability with private registries remains a major issue. Compatibility is also a major issue between entities such as CMOs, based on research conducted for WIPO by François Nuttall, a Senior Consultant for the International Confederation of Societies of Authors and Composers (CISAC). ${ }^{125}$ CISAC is one of the largest umbrella organisations of authors' societies. As of January 2015, it represented 230 authors' societies (CMOs) across 120 countries, primarily in the fields of music, audiovisual productions, drama, literature and the visual arts. ${ }^{126}$

Reviewing the gradual integration of individual members' records, Nuttall documents the adoption of technical standards for identifying authors, right holders, works and data relevant to transactions such as licensing arrangements. In a title-based property register, where ownership records are linked to the name of the protected work, accurately identifying both the owner and the work is crucially important - and hard. A key requirement is the need to disambiguate parties or works that have the same name (there are 139 artists whose

123 Carroll's conclusion is that - within the constraints of Art 5(2) of the Berne Convention - the way forward involves better integration between public and private registration systems while also regulating private registries, increasing transparency in their operations and facilitating interoperable technological solutions. MW Carroll, 'A Realist Approach to Copyright Law's Formalities' (2013) 28(3) Berkeley Technology Law Journal 1511.

124 WIPO, Summary of the Responses to the Questionnaire for Survey on Copyright Registration and Deposit Systems, (WIPO, 2010) 2.

125 FX Nuttall, Private Copyright Documentation Systems and Practices: Collective Management Organisations' Databases (Preliminary Version) (WIPO, 2011).

126 See $<$ www.cisac.org/Our-Members $>$. 
name includes 'Michael Jackson'), ${ }^{127}$ or where the name is expressed differently, such as with linguistic variances, not to mention the inevitable spelling mistakes. For ownership and remuneration tracing, the response is to assign a unique Party Identifier to the owner, as part of the metadata associated with a work. Options include the Interested Party Identifier (IPI) system used by CISAC, or the International Standard Name Identifier (ISNI), which is a draft ISO standard (ISO 27729). ${ }^{128}$ Again, the experience gained via private registration systems could inform the design of public copyright registries.

The second reason why private registries are of interest is that they operate almost entirely digitally. ${ }^{129}$ They allow a range of digital file formats to be deposited; use bar codes or other unique identifiers such as a permanent URL to identify registered works; and - in bypassing the examination stage (on which more below) - permit rapid or even real-time registration. ${ }^{130}$ Private registries have also experimented with applicant identity verification, identifying the work (using digital fingerprints and hash-codes) and recording the time of creation (using a trusted time stamp on upload). ${ }^{131}$ Initiatives to create a trustworthy environment for transactions, by clearly linking an author with her work, are also being developed in the context of Creative Commons registries such as Registered Commons. ${ }^{132}$ Those wishing to use CC-licensed materials need to be able to rely on the licence and proof of ownership is integral to this. This corpus of experience can be drawn upon when implementing national copyright registration systems.

127 Nuttall contrasts it with only one IPI \# 0002961801. See the presentation by F Nutall, 'Private Copyright Documentation Systems and Practices: Collective Management Organisations' Databases' (Conference on Copyright Documentation and Infrastructure, WIPO, Geneva Oct 2011).

128 Nuttall, Private Copyright Documentation Systems and Practices: Collective Management Organisations' Databases (Preliminary Version) (WIPO, 2011), 9-10. As an illustration, an ISNI is made up of 16 decimal digits, the last one being a check character; e.g. ISNI 1422458635730476. ISNIs are attached to the public identities of parties involved in creative processes. It operates as an open layer, above proprietary Party identification systems such as IPI.

129 The most prominent are Safe Creative, Registered Commons, Copyright Deposit, and Numly. They are described in Annex I of Nuttall (Private Copyright Documentation Systems and Practices: Collective Management Organisations' Databases (Preliminary Version) (WIPO, 2011)).

130 M Ricolfi et al, Survey of Private Copyright Documentation Systems and Practices (WIPO, 2011) 4-5.

131 Ibid, 11-13.

132 R Alton-Scheidl, J Benso and M Springer, 'The Value of Registering Creative Works' in MD de Rosnay and JC De Martin, The Digital Public Domain: Foundations for an Open Culture (Open Book Publishers, 2012) 189. 
Finally, turning to the question of institutional support for electronic registration, Lawrence Lessig has proposed publicly regulated private registrars, along the lines of the present domain name system. ${ }^{133}$ The global top-level domain name system provides a reference point since it consists of a central coordinating agency, the Internet Corporation for Assigned Names and Numbers (ICANN) which accredits the registrars actually registering top-level domain names. ${ }^{134}$ Given enormous numbers of potentially registrable works, the notion of parallel entry points into the registration system is appealing.

Copyright registrars could be allowed to compete via value-added services, while the copyright office would set out qualifying conditions for registrars to be recognised, monitor compliance, specify the minimum information required for each application, produce lists of acceptable verification methods and indicate technical specifications for the storage and transmission of data to ensure compatibility. However the ICANN experience suggests that it is important to have a public entity closely involved, for at least one very pragmatic reason: private registrars disappear (e.g. through bankruptcy). ICANN has developed a two-stage response to this. First, all registrars are required to 'escrow' their customers' domain name registration data, by forwarding it to a third party for safe keeping. ${ }^{135}$ Second, it created a De-Accredited Registrar Transition Procedure, under which a 'gaining registrar' is the recipient of a bulk transfer of domain names. ${ }^{136}$ This preserves ownership records and allows parties to use or transfer domains. Anecdotal evidence suggests that the 'longevity' of private copyright registrars is a genuine concern, especially given the extended duration of copyright term. ${ }^{137}$ Therefore while a hybrid public-private registrar network continues to be attractive, the OHIM and eCO examples considered above suggest that efficient public registrars are also viable prospects.

133 L Lessig, Free Culture: How Big Media Uses Technology and the Law to Lock Down Culture and Control Creativity (Penguin Press, 2004), 287-291.

134 An overview of the registrar accreditation process can be found at <www.icann.org/ resources/pages/accreditation-2012-02-25-en>.

135 See ICANN Registrar Accreditation Agreement (2013), [3.6], <www.icann.org/resources/ pages/approved-with-specs-2013-09-17-en>.

136 Available at <www.icann.org/en/system/files/files/dartp-11jull3-en.pdf $>$.

137 See Choosing a Copyright Registration Service at <www.copyrightaid.co.uk/advice/ copyright_registration>; M Ricolfi et al, Survey of Private Copyright Documentation Systems and Practices (WIPO, 2011), 35 n 85. 


\subsection{Legal effects and the timing question}

The evidence suggests there is potential for relatively fast, accessible and affordable electronic copyright registration systems. But should registration be mandatory? While patents and trademarks are supported by mandatory registration these regimes have historically belonged to the domain of industrial property with its attendant commercial logic. ${ }^{138}$ Section 3 identified concerns associated with the reintroduction of formalities. Registration-based systems tend to favour commercial parties and repeat players, but individuals are responsible for a great deal of creative output. Consider the blogger seeing her work reproduced, without authorisation, by a commercially motivated third party, or the photographer whose digital photograph is showcased on someone else's ecommerce site, without attribution or remuneration.

There are two potential responses - either alternatives or cumulative - to this concern. The first would be to continue granting copyright automatically upon creation, allowing an initial period of formalityfree protection but requiring mandatory registration in order to benefit from the remainder of the copyright term. As an example, US copyright law previously recognised an initial period of 28 years of automatic protection, although both registration and deposit were necessary before commencing with infringement proceedings even during this initial period. ${ }^{139}$ Mandating registration prior to litigation ensures that ownership information and the date of creation or publication are placed on public record. Otherwise it is difficult to determine whether a work has crossed the initial duration threshold (say 28 years) of automatic protection. ${ }^{140}$ This would grant the photographer or blogger automatic protection for a reasonable period, sufficient to allow them to assess the commercial significance of the work ex post creation. ${ }^{141}$ They would retain the option to subsequently register the work and

\footnotetext{
138 For the historic differences between literary and artistic property on the one hand and industrial property on the other; see WIPO, Introduction to Intellectual Property - Theory and Practice (Kluwer Law International, 1997) 3; J Hughes, 'A Short History of "Intellectual Property" in Relation to Copyright' (2012) 33 Cardozo Law Review 1293.

139 Copyright Act of 1909, ch 320, § 12, 35 Stat 1075, 1078 (repealed 1976).

140 However if protection for the initial period was conditioned upon a notice requirement, then registration could be entirely done away with for the initial period, including for the purposes of litigation.

141 On the average viable commercial lifespan for works, see R Giblin, 'Rethinking copyright's duration', this volume.
} 
enjoy extended protection. For those who did not opt for registration, a work could either fall into the public domain at one (extreme) end of the spectrum or the rights and remedies available might become restricted for unregistered works, which is explored below.

The second option would be to require registration at or around the time of publication of the work, as an obligatory requirement. Failing to do so would result in thinner protection being granted; a form of copyright-lite or Copyright 2.0. ${ }^{142}$ This two-tier copyright regime could be given effect by limiting the remedies available. Sprigman has proposed that the consequence of failing to comply with formalities would be to allow the work to be used under a compulsory licence, for a low royalty fee. More specifically, 'owners of unregistered works would continue to recover actual damages as measured by the reasonable value of a license, but they would be ineligible to receive either disgorgement or preliminary or permanent injunctive relief ${ }^{\prime} .{ }^{143}$ Copyright would effectively shift from a property to a liabilitybased regime for unregistered works, by limiting remedies to actual damages calculated based on the value of a licence negotiated $e x$ ante. The Copyright Principles Project proceeds along similar lines. Protection for unregistered works might be thin, being restricted to exact or near-exact copying, with other uses being deemed fair use. Additionally, remedies for infringing unregistered works would not include statutory damages or attorney's fees. Registered works would enjoy correspondingly broader rights and remedies. ${ }^{144}$ A combination of these two options is also possible - an initial period of automatic protection would be followed by a period of attenuated protection for unregistered works. What this demonstrates is that a suitably nuanced registration-based system could accommodate the concerns of the blogger, the amateur photographer or user/creators more generally.

142 Proposed by M Ricolfi, 'Consume and Share: Making Copyright Fit for the Digital Agenda' in C Geiger (ed), Constructing European Intellectual Property Law: Achievements and New Perspectives (Edward Elgar, 2013) 314 (arguing that, for cultural works, as production and distribution functions become more distributed, the pathway from creators to the public gets shorter and copyright should be correspondingly attenuated to the right to attribution, in the absence of a notice).

143 Sprigman, above n 56, 1567. See also Sprigman, above n 16.

144 Samuelson et al, above n 66, 1200-1201. 
There are two additional considerations which argue against imposing excessive penalties for non-registration. To begin with, there is the unfairness for those who inadvertently do not register, or lack the knowledge, means or capacity to do so. Additionally, exclusion from copyright protection might lead to a corresponding expansion of the scope of unfair competition law to accommodate such situations. ${ }^{145}$ In the past, utilitarian works, or those resulting from the sweat of the brow, ${ }^{146}$ or those closer to ideas rather than expression such as TV formats ${ }^{147}$ have been rehoused within unfair competition prevention regimes, where one of the central claims relates to the prevention of misappropriation of valuable intangibles. Unfair competition determinations are case-specific and lack many of the structural checks and balances of copyright law. Inadvertently encouraging its expansion into the domain of copyright is undesirable.

\subsection{Representative registration?}

Should the intangible object protected by copyright be identified by representative registration, described as the process whereby the creation was represented in pictorial or written terms rather than via a copy or a model'? $?^{148}$ The specification, claims, abstract and drawings of a patent or the graphical representation of a trademark reflect this approach to identifying the intangible objects of protection. This question is worth raising, if only to dismiss, because it serves as a reminder that a mandatory public copyright register would operate very differently from a patent, design or trademark register in terms of defining the scope of the intangible property and the boundaries of the work.

145 See R Callmann, 'Copyright and Unfair Competition' (1940) 2 Louisiana Law Review 648 (characterising the recognition of property in factual yet time sensitive 'hot news' as one such development).

146 T Scassa, 'Originality and Utilitarian Works: The Uneasy Relationship between Copyright Law and Unfair Competition' (2003-2004) University of Ottawa Law \& Technology Journal 55.

147 L Logan, 'The Emperor's New Clothes? The Way Forward: TV Format Protection under Unfair Competition Law in the United States, United Kingdom and France' (2009) Entertainment Law Review 37 (Part 1) and 87 (Part 2).

148 Sherman and Bently, above n 4, 72. 
Copyright registration has historically prioritised the ownership question ('who owns what') rather than the one of the scope ('what intangible expression is being claimed'). ${ }^{149}$ Characterising copyright as pre-modern, Sherman and Bently observe:

The difference between patents and copyright created by the different modes of identification was further enhanced by the fact that even if the law had chosen to use registration as a means of identifying the copyright work, this was said to have been excluded by the nature of the work protected. While it was possible to reduce the intangible property embodied in a machine to paper, it was said to have been impossible to capture the essence of literary and artistic works: 'who can give a specification for the making of an "Inferno"? If anyone undertakes to do so, it will not be a Dante, but a Dennis'. ${ }^{150}$

Therefore one powerful argument against representative registration was 'the belief that it was not possible to reduce the subject matter of copyright law beyond the material form in which it existed'. ${ }^{151}$ This argument was reinforced by the deposit requirement.

Stef van Gompel also identifies a historical trajectory, relating to the scope of protection, which counteracted any initiatives towards representative registration. In the early decades of copyright, thin protection against literal copying obviated the need for identifying the protected expression. 'The privileges and stationers' copyright protected these [registered] works against unauthorized reprinting, importation and distribution, but rarely against adaptation, translation or public performance. Thus, the two systems did not protect works qua abstractum, but the printed matter as such' ${ }^{152}$ During the latter part of the 19th century, the scope of protection was considerably extended, to protect works:

149 For a recent attempt to address the scope question through formalities, see PS Menell, 'Economic Analysis of Copyright Notice: Tracing and Scope in the Digital Age' (2016) 96 Boston University Law Review 967.

150 Sherman and Bently, above n 4, 154.

151 Ibid 183.

152 van Gompel, above n 5, [2.3.2.1]. As a counter-example, papal privileges extended protection to adaptations, translations and extensions of protected works. JC Ginsburg, 'Proto-Property in Literary and Artistic Works: 16th Century Papal Printing Privileges' (2013) 36 Columbia Journal of Law and the Arts 345, 358-361. 
qua abstractum, by focusing the protection on the personal and unique form of expression of the author's thoughts or ideas. This gave even more prominence to the intangible character of copyright and eventually led to the recognition of protection for the multiple ways in which a work could be exploited. ${ }^{153}$

This led to difficulties delimiting the work: with copyright defined in 'formalities seemed less indispensable for copyright protection. Rather than defining ex ante the essence and boundaries of the intangible property via formalities, it was left to the courts to demarcate the nature and limits of literary and artistic works ex post' ${ }^{154}$ It might be summarised thus: with thin protection against literal copying, defining the scope of protected expression was unnecessary; with more expansive protection, identifying it ex ante during registration was not practicable. The consequence is that copyright registration systems have prioritised the identification of owners with works, as designated by titles (e.g. book or song titles) and/or deposits of the physical (and now digital) embodiments of the works themselves.

Following through on its implications, Jeanne Fromer describes the process by which this impacts upon the scope of the monopoly being claimed: patent claims articulate boundaries, giving public notice of the extent of the patentee's rights, 'usually by listing [the] necessary and sufficient characteristics' of protected embodiments. ${ }^{155}$ Copyright, on the other hand 'implicitly adopted a system of central claiming by exemplar, requiring the articulation only of a prototypical member of the set of protected works ... Copyright protection then extends beyond the exemplar to substantially similar works, a set of works to be enumerated only down the road in case-by-case infringement litigation' ${ }^{156}$ With technology increasingly facilitating digital deposit, it seems likely that the 'central claiming by exemplar' approach to the scope of copyright will be reinforced by registration. Somewhat counterintuitively, better technology could ensure that copyright remains 'pre-modern' in this regard.

153 van Gompel, above n 5, [3.3.2.3].

154 Ibid.

155 JC Fromer, 'Claiming Intellectual Property' (2009) 76 University of Chicago Law Review $719,721$.

156 Ibid. 


\subsection{Comprehensive coverage or work-specific?}

The subject matter coverage of copyright registers requires an engagement with the debate over whether copyright systems are 'open' or 'closed'; whether the categories of subject matter should be confined to an expressly enumerated list or open-ended. ${ }^{157}$ Conventionally, the UK has been a prime example of the 'closed list' approach, whereby eight and only eight categories of works are entitled to protection. By contrast, under article L112-1 of its Intellectual Property Code, France protects the rights of authors in all works of the mind, whatever their kind, form of expression, merit or purpose'. Article L-112-2 proceeds to illustrate works of the mind that largely corresponds to the literary and artistic works found within article 2 of the Berne Convention - books and other writings; lectures; dramatic works; works of choreography; musical works; cinematographic works and so on. ${ }^{158}$

The challenge would be to accommodate an open-ended approach to subject matter within registration systems that have historically worked with narrower categories of specific works. To take one example, in jurisdictions which do not have a fixation or recording requirement, certain categories of works are protected (e.g. perfume) ${ }^{159}$ in the absence of an established convention for representing such subject matter. From the historical record it appears that registration systems and associated bureaucratic practices accreted around specific categories of subject matter - for instance, literary works and the Stationers Company Register, ${ }^{160}$ and the registers of CMOs. ${ }^{161}$ The subject matter categories will therefore continue to remain relevant for bureaucratic processing, as is illustrated by the US response to the WIPO survey: All copyright works can be registered, but the Register of Copyrights has specified certain administrative classes into which works are placed for purposes of deposit and registration with the Copyright

157 On this divide, see R Anthony Reese, 'What should copyright protect?', this volume.

158 T Aplin, 'Subject Matter' in E Derclaye (ed), Research Handbook on the Future of EU Copyright (Edward Elgar, 2009) 54-58.

159 See generally C Cronin, 'Genius in a Bottle: Perfume, Copyright, and Human Perception' (2008-2009) Journal of the Copyright Society USA 427.

160 For details, see Ch 2 of C Blagden, The Stationers Company: A History, 1403-1959 (Stanford University Press, 1960).

161 CMOs originated with early initiatives by groups of authors sharing a common in interest in a certain type of subject matter, as the basis for collectivizing. See D Gervais (ed), Collective Management of Copyright and Related Rights (Kluwer Law International, $2^{\text {nd }}$ ed, 2010). 
Office'. ${ }^{162}$ Therefore US registration practice requires applications to be channelled according to the more flexible 'Type of Work' and the administrative classification of a 'Class of Work', determined by the application form used. ${ }^{163}$ Despite bureaucratic registration processes working with pre-existing categories increasingly sophisticated search engine algorithms could add nuance, for example if subject matter categories are included as an optional keyword instead of forming the basis of a closed classification system. ${ }^{164}$ Alternatively, European trademark law provides a model: open-ended categories of signs are accommodated in the EUIPO database by providing a catch-all 'Other' heading in addition to discrete categories such as Word, Figurative, 3D and Colour marks. ${ }^{165}$

\subsection{Examination}

The briefest possible summary here might be: substantive examination is possible but undesirable. Substantive examination would evaluate ex ante subsistence criteria, such as qualifying as a recognised type of work, clearing an originality threshold and potentially satisfying a fixation requirement: such examination is conducted by the US. ${ }^{166}$ From the preceding analysis, it is evident that substantive examination would be in tension with (i) the speed, cost and ease of registration; as well as (ii) Fromer's characterisation of the scope of copyright resting on central claiming by exemplar. Courts would invariably refine the scope of the protected work during any infringement proceedings. To take a simple example, the fact that an examiner concludes a book is original will not preclude a court from later determining that

162 WIPO Registration Questionnaire - Response of the United States (30 June 2010).

163 Oliar et al, above n 91, 2221-2222.

164 As appears to be the case when searching through US copyright records at <www. copyright.gov/records/>.

165 See < euipo.europa.eu/eSearch/\#advanced/trademarks $>$.

166 See Ch 600: 'Examination Practices in the US Copyright Office', Compendium of US Copyright Office Practices (3rd ed, 2014). Cf TG Field, 'Originality: Does the Copyright Office Hide the Ball?' (2009) 37 AIPLA Quarterly Journal 425, 426 (registration is usually pro forma although there are very occasional originality-based objections). 
elements of it are in the public domain. A further reason for being sceptical is that the originality threshold is seen as modest in most jurisdictions, ${ }^{167}$ so examination may not filter out undeserving works.

\section{A modest model}

In the spirit of this volume, it is time to let go of the side of the pool and float a proposal. What might a 'mandatory' registrationbased copyright system look like - one which would aspire to be effective in terms of its informational content while simultaneously accommodating individual, possibly non-professional creators?

\section{How:}

- To begin with, it would inevitably be digital and facilitate e-filing, responding to historic perceptions of formalities as an onerous imposition, by drawing on today's comparable electronic registers to ensure relatively quick and inexpensive registration.

- This registration system could be managed either by a national (public) registrar - the national Copyright Office or equivalent - or, inspired by the domain name system, by a constellation of private registrars operating under the oversight of a public regulator. Some public involvement is unavoidable given the potential for private registrars to fail or withdraw. Countries would be left free to adopt either model, while public entities would also be engaged in the international coordination of copyright registration.

- In terms of e-filing registration requirements, experiments are already underway to generate unique identification codes for both works and owners, which would improve the quality of information contained in the register. There would be a clear choice in favour of digital deposits of entire works (where possible)

167 This has led to proposals to calibrate the degree of protection afforded in accordance with the degree of originality of the underlying work. See G Parchomovsky and A Stein, 'Originality' (2009) 95 Virginia Law Review 1506. See also, E Lavik and S van Gompel 'On the Prospects of Raising the Originality Requirement in Copyright Law: Perspectives from the Humanities' (2013) 60 Journal of the Copyright Society of the USA 387; J Miller, 'Hoisting Originality' (2009) 31 Cardozo Law Review 451. 
and representative registration is unlikely. Registration systems could draw on techniques already in use (such as OHIM's 'Other' classification) to process an indicative, yet open-ended, list of the most common types of works.

- At the time of registration, there would be no substantive examination of originality.

\section{Why:}

- Registration would continue to confer evidentiary advantages, such as proof of publication, fixation (reinforced by deposit), and a rebuttable presumption that the applicant is the right holder (author or first owner). It would also give constructive notice to the public and defeat a defence of innocent infringement.

- The purpose of registration would be to improve the quality and availability of ownership information so the consequences of nonregistration would be fashioned accordingly. During Phase One - a period of 10 years from creation - copyright would subsist and registration would only be a necessary precondition for infringement proceedings. Registration would permit proceedings to be brought for infringing conduct taking place even prior to registration. However this retrospective effect would be limited to injunctive relief and damages based on the actual loss suffered by the claimant. The recovery of costs/fees, gains-based damages and statutory damages (as applicable) would only be available for infringing acts which take place after registration. At the end of this period, Phase Two would commence for the duration of the copyright term. Registration would be a necessary precondition for infringement and it would only have prospective effects, opening up the full suite of remedies for infringement only taking place after registration.

- A strongly incentivised recordal system would encourage up-todate ownership information. This would facilitate a market for licences and clearly be in the interests of copyright owners.

- For Phase One, defendants who were genuinely unable to identify or locate the copyright holder because they were not registered could avail of an 'innocent infringer' defence.

- Across both Phases, moral rights such as the right to attribution (where possible) or integrity would remain available regardless of registration status. 
While registration at the time of creation is not mandatory, infringement becomes the point at which ownership information must be placed within a publicly accessible register. The system described above attempts to retain meaningful rights and remedies for creators while also balancing this against the interests of those who have infringed because they lack the necessary information for rights clearance. What this model has not addressed is the question of international copyright protection, which is greatly facilitated by the absence of formalities. Here too there are options. The proposed model would continue to recognise proprietary interests in Phase One, giving creators ample time to decide on whether to pursue registration. International recognition might in turn adopt some of the key features of WIPO's Madrid System for the International Registration of Marks. A single centralised application in one language and one set of fees is the gateway to a bundle of distinct but more conveniently managed national registrations. ${ }^{168}$ Readers may disagree with some of the details, but the model outlined here demonstrates that a contemporary registration system at the national level could strike a balance between the competing interests involved.

\section{Conclusion}

The copyright formalities debate helps to make all that is familiar strange once again. In recognising rights automatically, on the basis of creation, copyright law is an outlier. There are tremendous information costs associated with the opacity of the entitlements it generates. Liberated from the strictures of article 5(2) of the Berne Convention and equipped with the lessons learned from historic formalities, it is possible to fashion a more sensible yet sensitive system which responds to these critiques. This chapter demonstrates that a return to copyright registration is worthy of consideration, since the pragmatic concerns which engendered article 5(2) may no longer exist.

This chapter has argued that we ought to change the law and adopt mandatory registration if we could. In addition, its analysis is helpful in two further ways. First, optional copyright registration is the focus of renewed policy interest, as informed by recent empirical research

168 See <www.wipo.int/madrid/en/>. 
exploring the operation of existing public and private registries. In comparison to the other registration-based IP systems, voluntary copyright registration is still taking tentative steps but there are valuable lessons to be learned, as documented in section 4 , above.

Second, the formalities debate - and the registration option in particular - could act as a baseline when evaluating contemporary reform proposals. There is so much we could be asking of those making a claim to copyright protection, which we refrain from asking, in stark contrast to most other areas of IP law. Yet when it comes to proposed solutions for the orphan works problem, some options are extremely onerous on users and downstream creators, effectively (and inequitably) imposing on them all the burdens we have chosen to spare the initial creators. Consider for example the UK 'solution' introduced in 2014, ${ }^{169}$ which requires anyone desiring to make use of an apparent orphan work to (1) search the Orphan Works register, (2) conduct a 'diligent search' to establish that the owner cannot be identified, or if identified cannot be located, ${ }^{170}$ (3) and if the work is an orphan work, apply to the UK IP Office for a licence (paying both an application fee, and the determined licence fee), giving details of the search conducted. After all of this, the applicant may (if the IPO is satisfied a sufficient search has occurred, and that it is not against the public interest) obtain a non-exclusive licence authorising use of the orphan work(s), which applies only within the UK, and can last only up to seven years. ${ }^{171}$ Note the extent of ex ante obligations imposed on the user: ${ }^{172}$ we have

169 The Copyright and Rights in Performances (Certain Permitted Uses of Orphan Works) Regulations 2014 (UK) No 2861; The Copyright and Rights in Performances (Licensing of Orphan Works) Regulations 2014 (UK) No 2863.

170 Guidance for what constitutes a diligent search for different kinds of copyright material has been produced by the UK IPO: see <www.gov.uk/government/publications/orphan-worksdiligent-search-guidance-for-applicants $>$.

171 Cultural heritage institutions (CHIs), which include archives, libraries, museums, educational establishments and public service broadcasters, may conduct a diligent search and, if satisfied a work is an orphan work, make it accessible to the public, and copy it for the purposes of digitisation, preservation, cataloguing or indexing. Note that this exception covers literary, cinematographic and audiovisual works and sound recordings. It does not include standalone artistic works like photographs, maps, plans and drawings.

$172 \mathrm{Cf}$ other proposals for addressing Orphan Works which are ex post: in the sense that use can occur without applying for a licence, with limitations on remedies in the event that a copyright owner comes forward after use commences. For a review and discussion of ex ante versus ex post systems, see Marcella Favale et al, 'Copyright, and the Regulation of Orphan Works: A comparative review of seven jurisdictions and a rights clearance simulation' (CREATe Working Paper No 2013/7, July 2013), available at <zenodo.org/record/8377/files/CREATe-WorkingPaper-2013-07.pdf>. 
essentially flipped the formalities burden onto downstream creative activity and cultural reuses. The formalities debate - the fact that we could have notice, registration and recordation but have chosen not to, for reasons which favour right holders at the cost of others with a legitimate interest in copyright protected works - should also be borne in mind when considering proposals to regulate and reform CMOs. Drawing back even further, the formalities debate serves as a reminder that the world we inhabit wasn't always this way, we do have choices and reimagining what copyright might be is the first step in any project to reform it. 
This text is taken from What if we could reimagine copyright?, edited by Rebecca Giblin and Kimberlee Weatherall, published 2017 by ANU Press, The Australian National University, Canberra, Australia. 